\title{
Trial by CCN2: a standardized test for fibroproliferative disease?
}

\author{
Andrew Leask
}

Received: 26 January 2009 / Accepted: 26 February 2009/Published online: 7 March 2009

(C) The Author(s) 2009. This article is published with open access at Springerlink.com

\begin{abstract}
A major issue concerning clinical trials is the availability of standardized assays to evaluate drug efficacy. Ideally, such assays should test the effect of a putative drug on the expression of a biomarker in biological fluids. In a recent study by Kuiper et al. (PLOS One, 3(7): e2675). The relative levels of vascular endothelial growth factor (VEGF) and CCN2 (connective tissue growth factor [CTGF]) were examined in proliferative diabetic retinopathy (PDR). This paper is the subject of this commentary.
\end{abstract}

\section{Keywords CTGF. CCN2}

Problems involving clinical trials for chronic fibroproliferative disease are the long duration of the trial (due to relatively slow disease progression) and difficult-to-detect endpoints that may not be successfully standardized from center to center. The availability of a relatively inexpensive, easy-to-perform assay with high signal-to-noise ratio would be highly beneficial.

$\mathrm{CCN} 2$, a cysteine-rich secretory protein of 36 to $38 \mathrm{kDa}$ that has four distinct modules, is largely regulated at the level of gene transcription (Blom et al. 2002). CCN2 is characteristically overexpressed in a wide variety of fibrotic disorders, and thus may represent an ideal surrogate biomarker for these diseases (Leask et al. 2009).

\footnotetext{
A. Leask $(\bowtie)$

Canadian Institutes of Health Research Group in Skeletal

Development and Remodeling,

Division of Oral Biology and Department of Physiology

and Pharmacology, Schulich School of Medicine \& Dentistry,

University of Western Ontario,

London, ON, Canada N6A 5C1

e-mail: andrew.leask@schulich.uwo.ca
}

Blindness from proliferative diabetic retinopathy (PDR) is caused by angiogenesis and fibrosis in the vitreous cavity of the eye. In this condition, neovascularization is accompanied by inflammation and fibrosis, and the appearance of myofibroblasts (Fong et al. 2004). There is no treatment for PDR.

In a recent report, Kuiper et al. (2008) used ELISAs to monitor the expression of CCN2 and VEGF proteins in the vitreous of PDR patients. CCN2 levels were using sandwich ELISAs, using two distinct monoclonal antibodies specifically recognizing the N-terminal part of the CCN2 (FibroGen). VEGF 165 levels were also determined by means of sandwich ELISA a (R\&D Systems). Vitreous CCN2 levels were significantly associated with degree of fibrosis and with VEGF levels, but not with neovascularization, whereas VEGF levels were associated only with neovascularization. The ratio of CCN2 to VEGF was the strongest predictor of degree of fibrosis.

To my knowledge, no study has examined both the levels of CCN2 and VEGF in a fibroproliferative condition. These data provide an exciting insight not only into the basis for fibrogenesis in the eye, but also open up the thrilling possibility, from a clinical perspective, of being able in the future to effectively monitor disease progression and drug efficacy in clinical trials. The next goal presumably would be to widely test these ideas in a variety of longitudinal trials, in pilot studies with actual compounds, and in other systems.

Open Access This article is distributed under the terms of the Creative Commons Attribution Noncommercial License which permits any noncommercial use, distribution, and reproduction in any medium, provided the original author(s) and source are credited. 


\section{References}

Blom IE, Goldschmeding R, Leask A (2002) Gene regulation of CTGF: New targets for antifibrotic therapy? Matrix Biol 21:473482. doi:10.1016/S0945-053X(02) 00055-0

Fong DS, Aiello LP, Ferris FL 3rd, Klein R (2004) Diabetic retinopathy. Diabetes Care 27:2540-2553. doi:10.2337/diacare. 27.10.2540
Kuiper EJ, Van Nieuwenhoven FA, de Smet MD, van Meurs JC, Tanck MW, Oliver N, Klaassen I, Van Noorden CJ, Goldschmeding R, Schlingemann RO (2008) The angio-fibrotic switch of VEGF and CTGF in proliferative diabetic retinopathy. PLoS One 3(7):e2675. doi:10.1371/journal.pone.0002675

Leask A, Parapuram SK, Shiwen X Abraham DJ (2009). Connective tissue growth factor (CTGF, CCN2) gene expression: a potent clinical marker of fibroproliferative disease. J. Cell Commun Signal., epub 